\title{
Desflurane preconditioning protects human umbilical vein endothelial cells against anoxia/reoxygenation by upregulating NLRP12 and inhibiting non-canonical nuclear factor- $\kappa B$ signaling
}

\author{
ZHIRONG SUN ${ }^{1}$, JIANING $\mathrm{LV}^{2}$, YUN ZHU ${ }^{1}$, DONGLI SONG ${ }^{3}$, BIAO ZHU ${ }^{4}$ and CHANGHONG MIAO ${ }^{4}$ \\ ${ }^{1}$ Department of Anesthesiology, Fudan University Shanghai Cancer Center; ${ }^{2}$ Department of Neurology, \\ Fudan University Shanghai Zhongshan Hospital; ${ }^{3}$ Biomedical Research Center, Fudan University Zhongshan Hospital; \\ ${ }^{4}$ Department of Anesthesiology and Critical Care Unit, Fudan University Shanghai Cancer Center, Shanghai, P.R. China
}

Received February 28, 2015; Accepted July 29, 2015

DOI: $10.3892 /$ ijmm.2015.2335

\begin{abstract}
Volatile anesthetics modulate endothelial cell apoptosis and inhibit nuclear factor- $\kappa \mathrm{B}(\mathrm{NF}-\kappa \mathrm{B})$ signaling. In this study, we aimed to assess whether desflurane preconditioning protects human umbilical vein endothelial cells (HUVECs) agaist anoxia/reoxygenation (A/R) injury. HUVECs were preconditioned with desflurane (1.0 MAC) for $30 \mathrm{~min}$, followed by a 15 -min washout, then exposed to $60 \mathrm{~min}$ anoxia and $60 \mathrm{~min}$ reoxygenation $(\mathrm{A} / \mathrm{R})$, and incubated with $10 \mathrm{ng} / \mathrm{ml}$ tumor necrosis factor (TNF)- $\alpha$ for $60 \mathrm{~min}$. HUVEC viability and apoptosis were measured by MTT assay and Annexin V staining, and immunoblot analysis was used to measure the levels of Smac and cellular inhibitor of apoptosis 1 (cIAP1). $\mathrm{NF}-\kappa \mathrm{B}$ activation was assessed using the NF- $\kappa \mathrm{B}$ signaling pathway real-time PCR array, and the levels of NF- $\kappa B$ inducing kinase (NIK), p52, IкB kinase (IKK) $\alpha$, p100, RelB and NLR family, pyrin domain containing 12 (NLRP12) were assessed by immunoblot analysis. Desflurane preconditioning attenuated the effects of $\mathrm{A} / \mathrm{R}$ and/or $\mathrm{A} / \mathrm{R}$ plus TNF- $\alpha$ on cell viability, decreasing the levels of Smac and enhancing the levels of of cIAP1 $(\mathrm{P}<0.05)$. Preconditioning with desflurane also enhanced the mRNA levels of interleukin (IL)-10 and NLRP12 in the cells exposed to A/R by 2.40- and 2.16-fold, respectively. The HUVECs exposed to A/R had greater levels of NIK and p100 and reduced levels of p52 and IKK $\alpha$. Desflurance preconditioning further increased p100 levels, decreased the level of NIK, further decreased $\mathrm{p} 52$ levels and further reduced IKK $\alpha$ levels. A/R in combination with TNF- $\alpha$ increased the NIK, IKK $\alpha$, p100 and RelB levels, and this increase was significantly attenuated by desflurance preconditioning (all $\mathrm{P}<0.05$ ).
\end{abstract}

Correspondence to: Dr Changhong Miao or Dr Biao Zhu, Department of Anesthesiology and Critical Care Unit, Fudan University Shanghai Cancer Center, 270 Dong An Road, Shanghai 200032, P.R. China

E-mail: miaochanghonganes@126.com

E-mail: biaozhuzs@sohu.com

Key words: desflurane preconditioning, NLRP12, nuclear factor- $\kappa \mathrm{B}$, human umbilical vein endothelial cells, anoxia/reoxygenation
Desflurane preconditioning enhanced HUVEC survival and protected the cells against A/R injury, and our results suggested that this process involved the upregulation of NLRP12 and the inhibition of non-canonical $\mathrm{NF}-\kappa \mathrm{B}$ signaling.

\section{Introduction}

Ischemia-reperfusion injury involves cellular responses to anoxia/reoxygenation (A/R), which initiate a cascade of cellular processes and molecular events that cause endothelial cell apoptosis (1-7). Volatile anesthetics have been demonstrated to induce caspase-dependent, mitochondrial-mediated apoptosis in vitro (8). However, preconditioning with volatile anesthetics, including desflurane, halothane, isoflurane and sevoflurane has been reported to protect against $\mathrm{A} / \mathrm{R}$ injury both in vivo and in vitro (9-11). Preconditioning with volatile anesthetics has been reported to affect inflammation (12-16), and we have previously reported that desflurane preconditioning protects human umbilical vein endothelial cells (HUVECs) against A/R injury through a process involving nuclear factor- $\kappa \mathrm{B}(\mathrm{NF}-\kappa \mathrm{B})(17,18)$.

The Rel-NF- $\kappa \mathrm{B}$ family of transcription factors has been implicated in a variety of biological functions, including cellular proliferation and apoptosis, and in the initiation and propagation of innate and adaptive immune responses (19-22). Rel-NF-кB activates two distinct $\mathrm{NF}-\kappa \mathrm{B}$ activation pathways: the canonical and non-canonical NF- $\kappa \mathrm{B}$ pathways $(23,24)$. The canonical $\mathrm{NF}-\kappa \mathrm{B}$ pathway is activated by the most stressful stimuli, and results in the IкB kinase (IKK) complex-mediated degradation of $\mathrm{I} \kappa \mathrm{B}$ and the rapid nuclear accumulation of p50-RelA and p50-cRel NF- $\kappa$ B complexes (25). By contrast, the non-canonical NF- $\kappa \mathrm{B}$ pathway is activated by a group of tumor necrosis factor (TNF) receptors, such as CD40 (26), lymphotoxin $\beta$ receptor (LT $\beta$ R) (27) and BAFF receptor (BAFF-R) (28). The activation of the non-canonical $\mathrm{NF}-\kappa \mathrm{B}$ pathway results in the degradation of the C-terminus of p100 into p52 and the translocation of p52 into the nucleus. In the nucleus, p52 combines with RelB, producing the NF- $\mathrm{BB}$ complex (29).

The Nod-like receptor (NLR) family contributes either directly or indirectly to a variety of hallmarks associated with cancer, including inflammation, cell death, tumor growth, angiogenesis, invasion and metastasis (30-34). NLRs have 
been traditionally considered as pattern-recognition receptors (PRRs), as they are activated in response to conserved structural motifs found in microbes or pathogen-associated molecular patterns (PAMPs). There is a subgroup of NLRs that negatively regulate inflammation (35-37), currently including three NLR family members, NLRP12, NLRX1 and NLRC3. NLRP12 (previously known as Monarch-1, PYPAF7, or CLR19.3) is one of the first to be well described and is the most well characterized member of this subgroup. It has been demonstrated in vitro that the overexpression of NLRP12 induces the transcription of an $\mathrm{NF}-\kappa \mathrm{B}$ reporter construct (38), suggesting that it is an inflammasome-forming NLR and a positive regulator of $\mathrm{NF}-\kappa \mathrm{B}$ signaling. However, under physiological conditions and in the context of human disease, the ability of NLRP12 to form a functional inflammasome appears to occur only under highly specific conditions $(39,40)$. In fact, several studies have evaluated NLRP12 inflammasome formation and have directly shown that NLRP12 does not regulate IL-1 $\beta /$ IL-18 maturation (41-46). Studies on NLRP12 have indicated that it functions as a negative regulator of inflammation by modulating canonical and non-canonical NF- $\kappa \mathrm{B}$ signaling $(37,42,44-46)$. NLRP12 negatively regulates non-canonical $\mathrm{NF}-\kappa \mathrm{B}$ signaling through its association with TRAF3 and NF- $\kappa$ B-inducing kinase (NIK) $(37,42)$.

In the present study, we investigated whether the protective effects of desflurane preconditiong against $A / R$ injury are mediated by the downregulation of the non-canonical NF- $\kappa \mathrm{B}$ signaling pathway.

\section{Materials and methods}

Primary culture of HUVECs. HUVECs were isolated from the human umbilical vein vascular wall using collagenase (Roche Diagnostics, Indianapolis, IN, USA) digestion, as previously described (47), and cultured in a humidified atmosphere containing $95 \% \mathrm{O}_{2}$ and $5 \% \mathrm{CO}_{2}$ at $37^{\circ} \mathrm{C}$ in endothelial cell culture medium (ECM; Sciencell Research Laboratories, Carlsbad, CA, USA) supplemented with $5 \%$ fetal bovine serum (FBS; Gibco-Life Technologies, Grand Island, NY, USA), $1 \%$ endothelial cell growth supplement (ECGS), $100 \mathrm{U} / \mathrm{ml}$ penicillin and $100 \mu \mathrm{g} / \mathrm{ml}$ streptomycin sulfate (all from Sciencell Research Laboratories). Cells were passaged 3-6 times before being used in the experiments. Ethics approval for the isolation of the HUVECs was obtained from the Ethics Committee of Fudan University Shanghai Cancer Center, Shanghai, China.

Immunofluorescence staining. Confluent endothelial cells in monolayer were fixed with $95 \%$ cold ethanol for $5 \mathrm{~min}$ (the cells were grown on sterile glass cover slides overnight at $37^{\circ} \mathrm{C}$. The slides were briefly washed 3 times for $5 \mathrm{~min}$ in PBS, and then fixed with $95 \%$ cold ethanol and air dried). A drop of diluted anti-rabbit human factor VIII antibody (Abcam, Cambridge, $\mathrm{UK}$ ) was added (1:10 dilution), allowed to react for $30 \mathrm{~min}$ in a moisture chamber, and then washed 3 times for $5 \mathrm{~min}$ in PBS. The slide was then incubated for $45 \mathrm{~min}$ at $37^{\circ} \mathrm{C}$ with FITCconjugated goat anti-rabbit globulin (Cwbiotech, Shanghai, China) at a 1:50 dilution, and the washing procedure was then repeated. A drop of mounting fluid consisting of $10 \%$ glycerol, $90 \% \mathrm{PBS}$ and $0.25 \mathrm{mg} / \mathrm{ml}$ propidium iodide (PI; Cwbiotech) for counterstaining the nuclei was added. The slides were examined on a coverslip under an epifluorescence microscope (Olympus, Tokyo, Japan) (Fig. 1), as previously described (48).

Desflurane preconditioning and the $A / R$ regimen. An in vitro model of A/R, which has been previously described (49), was used in the present study. The HUVECs were subjected to a period of anoxia, during which the cells were incubated in $95 \% \mathrm{~N}_{2}$ and $5 \% \mathrm{CO}_{2}$ for $60 \mathrm{~min}$, followed by $60 \mathrm{~min}$ reoxygenation, during which time the cells were incubated in $95 \% \mathrm{O}_{2}$ and $5 \% \mathrm{CO}_{2}$. Prior to exposure to $\mathrm{A} / \mathrm{R}$, the cells were incubated in the presence or absence of desflurane (1.0 MAC) for $30 \mathrm{~min}$, and then allowed to rest for $15 \mathrm{~min}$. Immediately after the A/R protocol, the cells were incubated in the presence or absence of $10 \mathrm{ng} / \mathrm{ml}$ recombitant human TNF- $\alpha$ (rhTNF- $\alpha$ ) (ProSpec, Ness Ziona, Israel) for $60 \mathrm{~min}$ (Fig. 2).

Assessment of cell viability. An MTT assay was used, as tetrazolium salts are cleaved to form a formazan dye only by metabolically active cells and are particularly useful for quantifying the number of viable cells. The HUVECs were seeded in 96-well plates (3x10 cells/well) and incubated overnight for complete cell adhesion. On the second day, desflurane preconditioning and $\mathrm{A} / \mathrm{R}$ exposure were carried out as described above. At the end point of the experiment, MTT (50 $\mu \mathrm{l} /$ well; Beyotime Institute of Biotechnology, Haimen, China) was added to the medium followed by incubation at $37^{\circ} \mathrm{C}$ for a further $4 \mathrm{~h}$. The medium was removed from all wells, and the insoluble formazan product was dissolved in $150 \mu \mathrm{l}$ of DMSO for $10 \mathrm{~min}$ at room temperature. The optical density (OD) of each culture/ well was measured using a spectrophotometer (UV-2450/2550, Shimadzu Corp., Tokyo, Japan) at $550 \mathrm{~nm}$. The OD of the cells in the control group represented $100 \%$ viability.

Flow cytometric analysis. Cell apoptosis was detected by flow cytometry. Cells were double-stained with Annexin V-FITC and PI (Beyotime Institute of Biotechnology) according to the manufacturer's instructions, and cell fluorescence was analyzed on a FACSan flow cytometer. Annexin V-FITC-positive cells reflected the relative proportion of apoptotic cells.

PCR array. Total RNA was extracted using TRIzol reagent (Invitrogen, Carlsbad, CA, USA). The expression of inflammatory genes was examined by real-time PCR, utilizing the NF- $\mathrm{B}$ signaling pathway $\mathrm{RT}^{2}$ RNA QC PCR array (PAHS025; Qiagen, Inc., Valencia, CA, USA), which profiled the expression of 84 key genes related to NF- $\kappa \mathrm{B}-$ mediated signal transduction. The expression of the genes of interest (84 key genes related to $\mathrm{NF}-\kappa \mathrm{B}-$ mediated signal transduction) was compared between the treated and untreated cells. The fold change in expression for each gene between the treated and untreated cells was calculated using the $2^{-\Delta \Delta C t}$ method (Shanghai Kangcheng Biological Engineering Co., Ltd. Shanghai, China).

Immunoblot analysis. Cells were harvested and homogenized using RIPA lysis buffer (Beyotime Institute of Biotechnology). Proteins were separated on $8 \%$ SDS-PAGE gels and transferred onto polyvinylidene fluoride (PVDF) membranes (Millipore, Billerica, MA, USA). The membranes were blocked with $5 \%$ non-fat dry milk in TBST (containing $0.05 \%$ Tween-20), and incubated overnight at $4^{\circ} \mathrm{C}$ with the following primary anti- 
Factor VIII-FITC

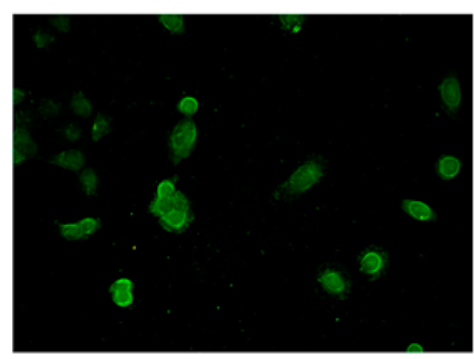

PI

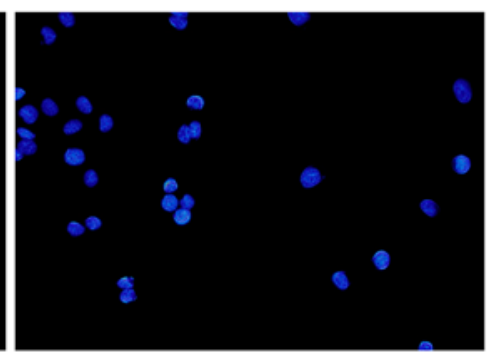

Merged

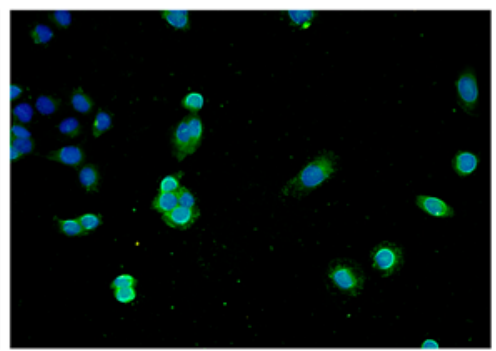

Figure 1. Expression of factor VIII in isolated human umbilical vein endothelial cells (HUVECs) (original magnification, $\mathrm{x} 40$ ). HUVECs were isolated from human umbilical vein vascular wall by collagenase digestion, and cultured ex vivo. HUVEC phynotype was confirmed by factor VIII staining (green), and propidium iodide (PI) staining (blue), and analyzed by immunofluorescence.

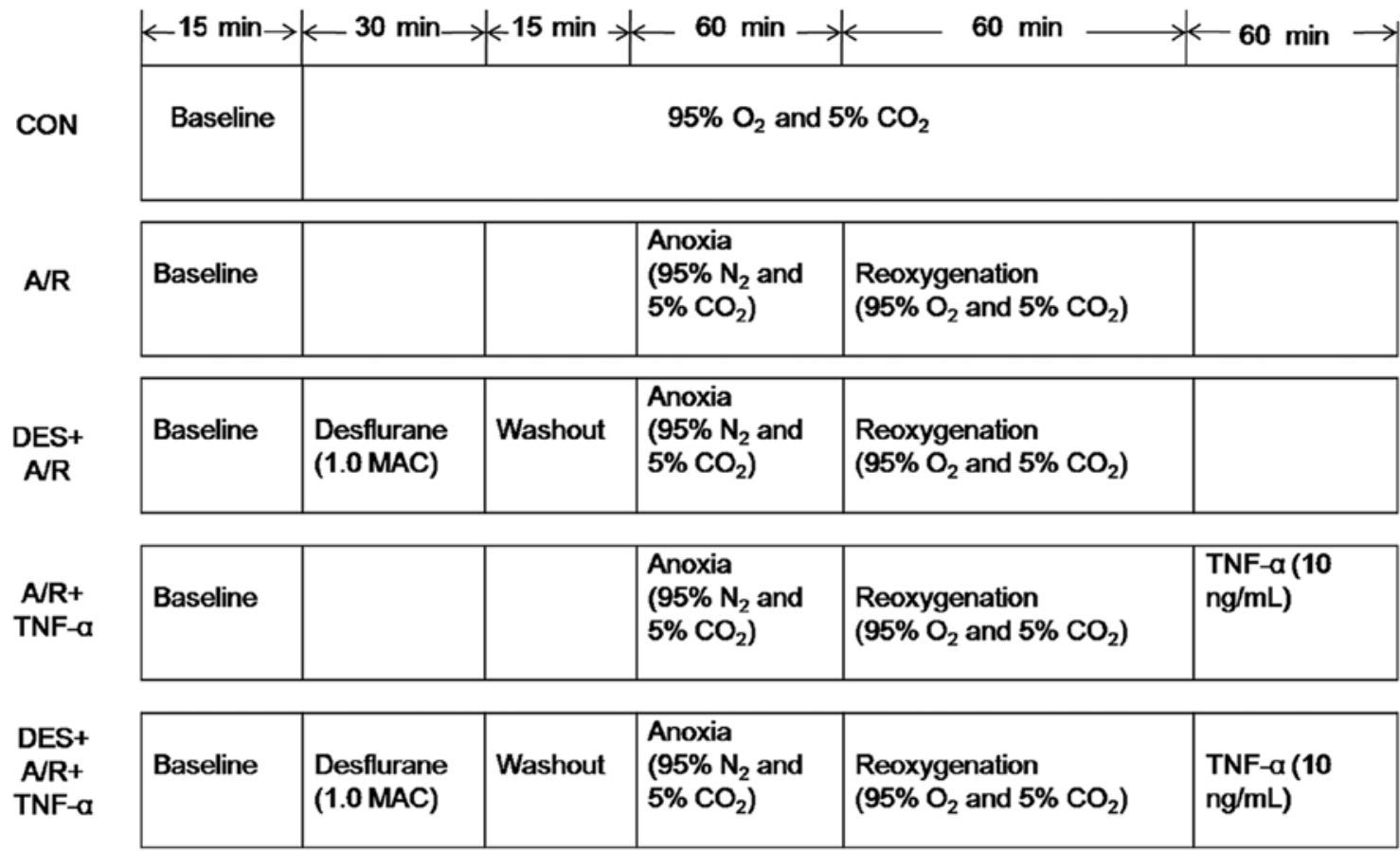

Figure 2. Desflurane preconditioning and anoxia/reoxygenation exposure protocol. As described in the Materials and methods, after 3 to 6 passages ex vivo, the HUVECs were incubated in the presence or absence of $1.0 \mathrm{MAC}$ desflurane for $30 \mathrm{~min}$, followed by a 15 -min washout period before $\mathrm{A} / \mathrm{R}$, and in the presence or absence of $10 \mathrm{ng} / \mathrm{ml}$ tumor necrosis factor (TNF)- $\alpha$ for $60 \mathrm{~min}$ after A/R. CON, control; A/R, anoxia/reoxygenation; DES+A/R, desflurane preconditioning and anoxia/reoxygenation; A/R + TNF- $\alpha$, anoxia/reoxygenation and tumor necrosis factor- $\alpha(10 \mathrm{ng} / \mathrm{ml}) ; \mathrm{DES}+\mathrm{A} / \mathrm{R}+\mathrm{TNF}-\alpha$, desflurane preconditioning, anoxia/rexoygenation and tumor necrosis factor- $\alpha(10 \mathrm{ng} / \mathrm{ml})$.

bodies: NLR family, pyrin domain containing 12 (NLRP12; sc-99175), (Santa Cruz Biotechnology, Santa Cruz, CA, USA), Smac (2952), cellular inhibitor of apoptosis 1 (c-IAP1; 4592), NIK, IKK $\alpha$, p100/p52, RelB (included in the Non-Canonical Pathway Antibody Sampler kit) (all from Cell Signaling Technology, Danvers, MA, USA), GAPDH (AG019; Beyotime Institute of Biotechnology) and $\beta$-actin (A2668; Sigma, St. Louis, MO, USA). The blots were then washed and incubated with horseradish peroxidase-conjugated goat anti-mouse IgG (sc-2005; Santa Cruz Biotechnology) for $1 \mathrm{~h}$ at room temperature. Immunoreactivity was enhanced with a chemiluminescence kit (Millipore) and exposed to film. GAPDH (Beyotime Institute of Biotechnology) or $\beta$-actin (Sigma) were used as internal controls. The density of the bands on the blots was quantified using a Bio-Rad imaging system (Bio-Rad Laboratories, Hercules, CA, USA).
Statistical analysis. Data are expressed as the means $\pm \mathrm{SD}$, and were analyzed using one-way analysis of variance (ANOVA), followed by the Student-Newman-Keuls test. A P-value $<0.05$ was considered to represent a statistically significant difference. All analyses were conducted using SPSS 13.0 software (SPSS, Inc., Chicago, IL, USA).

\section{Results}

Effect of desflurane preconditioning on A/R-induced damage to HUVECs

Desflurane preconditioning promotes HUVEC survival during $A / R$. As previously established, exposure to A/R and/or TNF- $\alpha$ reduces HUVEC viability (50). In this study, we detected HUVEC viability by MTT assay, and found that our A/R protocol significantly reduced HUVEC viability $(\mathrm{P}<0.05)$, and 
A

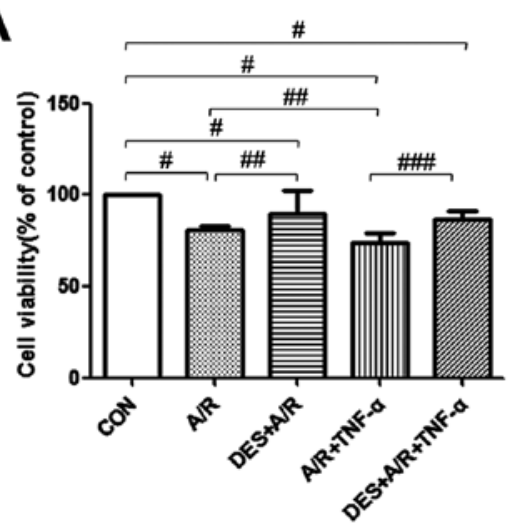

B

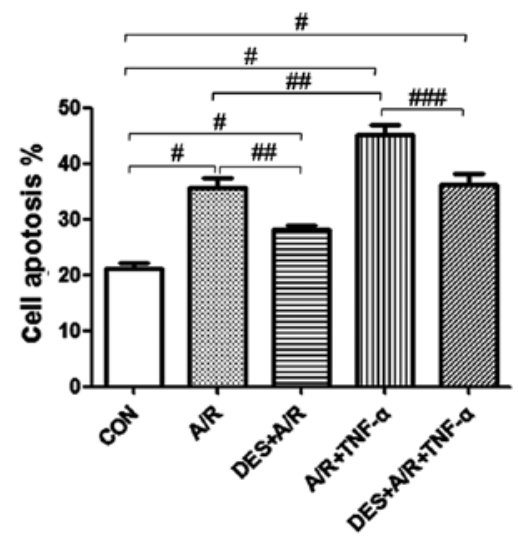

C
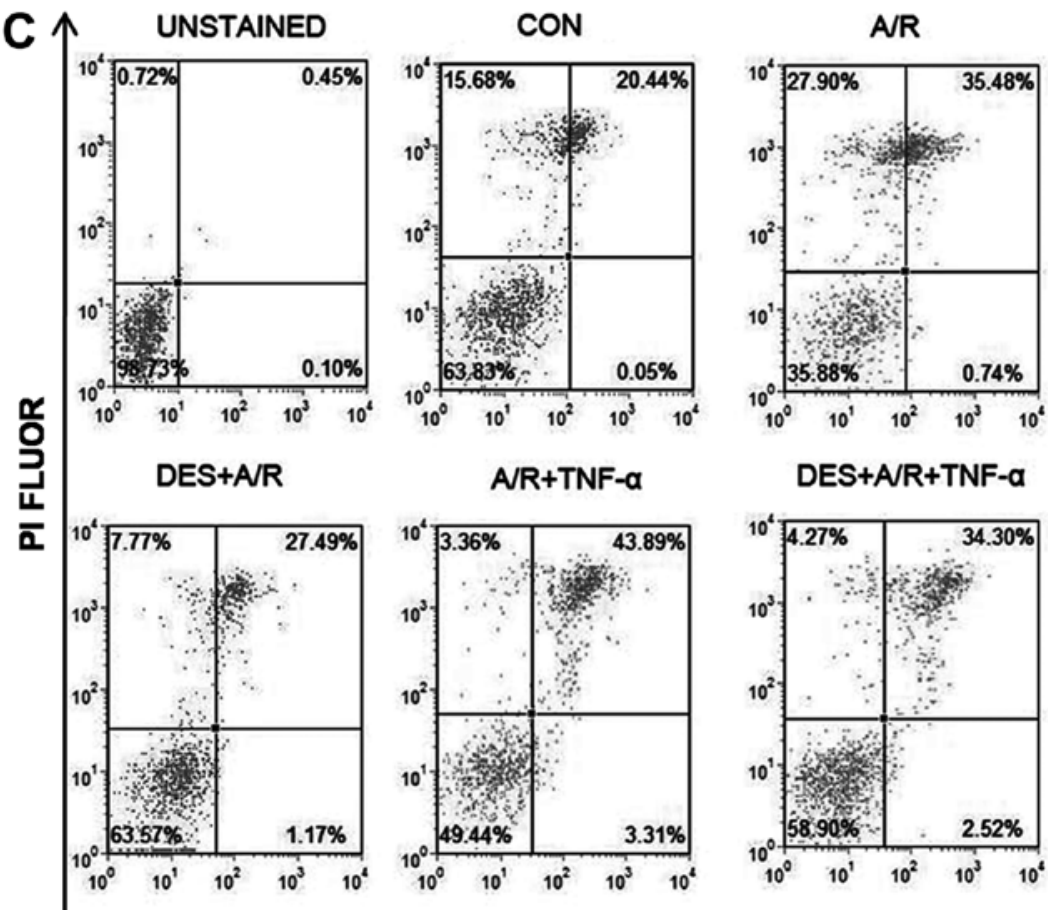

DES+AR+TNF-a
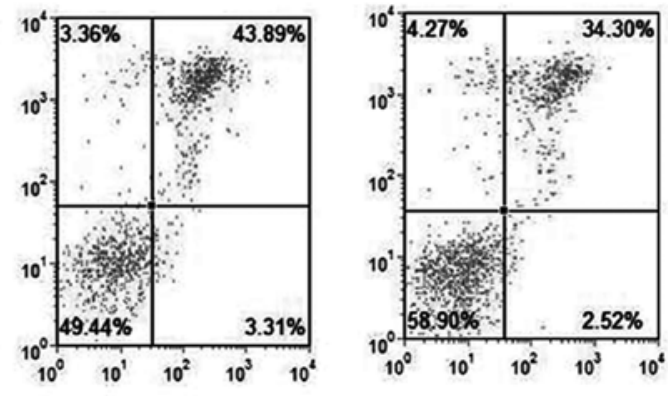

FITC-conjugated Annexin V FLUOR

Figure 3. Desflurane preconditioning (DES) attenuates anoxia/reoxygenation (A/R) injury in human umbilical vein endothelial cells (HUVECs). (A) HUVECs were incubated with $1.0 \mathrm{MAC}$ desflurane, $10 \mathrm{ng} / \mathrm{ml}$ tumor necrosis factor (TNF)- $\alpha$ and/or exposed to A/R as indicated in Fig. 2. Cellular viability was measured by MTT assay. (B and C) Apoptosis was assessed by propidium iodide (PI) and Annexin V staining, analyzed by flow cytometric analysis, and the data in (B) were derived from $(\mathrm{C})$. Data represent the means \pm SD of 3 independent experiments. ${ }^{\#} \mathrm{P}<0.05$ vs. control $(\mathrm{CON}),{ }^{\# \#} \mathrm{P}<0.05$ vs. $\mathrm{A} / \mathrm{R},{ }^{\# \# \#} \mathrm{P}<0.05$ vs. A/R $+\mathrm{TNF}-\alpha$.

when $\mathrm{A} / \mathrm{R}$ was followed by incubation with TNF- $\alpha$, HUVEC viability was further reduced $(\mathrm{P}<0.05$; Fig. 3A). However, desflurane (1.0 MAC) preconditioning significantly attenuated the effects of $\mathrm{A} / \mathrm{R}$ or $\mathrm{A} / \mathrm{R}$ and TNF- $\alpha$ on HUVEC viability $(\mathrm{P}<0.05$; Fig. 3A), suggesting that desflurane preconditioning promotes HUVEC survival under certain conditions of cellular stress.

Desflurane preconditioning decreases the apoptosis of HUVECs exposed to $A / R$. The rate of apoptosis was determined by Annexin V and PI staining, and analyzed by flow cytometry. Spontaneous apoptosis was low in the HUVECs in the control group, whereas exposure to $\mathrm{A} / \mathrm{R}$ increased apoptosis $(\mathrm{P}<0.05)$, and when $\mathrm{A} / \mathrm{R}$ was followed by incubation with TNF- $\alpha$, HUVEC apoptosis increased even further $(\mathrm{P}<0.05)$. Pre-treatment with desflurane (1.0 MAC) attenuated the effects of $\mathrm{A} / \mathrm{R}$ or $\mathrm{A} / \mathrm{R}$ and THF- $\alpha$ on HUVEC apoptosis $(\mathrm{P}<0.05)$ (Fig. 3B and C), suggesting that desflurane preconditioning protects HUVECs against $\mathrm{A} / \mathrm{R}$ induced apoptosis.
Desflurane preconditioning increases the expression of cIAPI and decreases the expression of Smac. In order to further elucidate the effects of desflurane preconditioning on A/R-induced HUVEC apoptosis, we examined Smac activation and cIAP1 inhibition, as these are processes unique to apoptosis, which do not occur in other forms of cell death. We detected increased levels of Smac and cIAP1 in the HUVECs exposed to $\mathrm{A} / \mathrm{R}$ and $\mathrm{A} / \mathrm{R}$ plus TNF- $\alpha(\mathrm{P}<0.05)$. Desflurance preconditioning increased c-IAP1 levels $(\mathrm{P}<0.05)$ and decreased the levels of Smac ( $\mathrm{P}<0.05$; Fig. 4), suggesting that desflurane preconditioning protects HUVECs against A/R-induced apoptosis through a mechanism involving the inhibition of Smac and the activation of cIAP1.

Desflurane preconditioning affects the expression of inflammatory genes. In the HUVECs exposed to $\mathrm{A} / \mathrm{R}$ or $\mathrm{A} / \mathrm{R}$ plus TNF- $\alpha$, elevated protein levels of NLRP12 (a regulator of 
Table I. IL-10 and NLRP12 mRNA expression in HUVECs in response to A/R and desflurane preconditioning.

\begin{tabular}{|c|c|c|c|c|c|}
\hline $\begin{array}{l}\text { Gene } \\
\text { symbol }\end{array}$ & Gene name & GenBank accession no. & Description & $\begin{array}{r}\text { Upregulation } \\
\text { (fold change) }\end{array}$ & $\begin{array}{l}\text { Downregulation } \\
\text { (fold change) }\end{array}$ \\
\hline IL-10 & $\begin{array}{l}\text { CSIF/IL-10/IL-10A/ } \\
\text { MGC126450/ } \\
\text { MGC126451/TGIF }\end{array}$ & NM_000572 & Interleukin 10 & 2.40 & \\
\hline NLRP12 & $\begin{array}{l}\text { CLR19.3/FCAS2/ } \\
\text { NALP12/PAN6/ } \\
\text { PYPAF7/RNO/RNO2 }\end{array}$ & NM_033297 & $\begin{array}{l}\text { NLR family, } \\
\text { pyrin domain containing } 12\end{array}$ & 2.16 & \\
\hline
\end{tabular}

HUVECs, human umbilical vein endothelial cells; A/R, anoxia/reoxygenation.

A
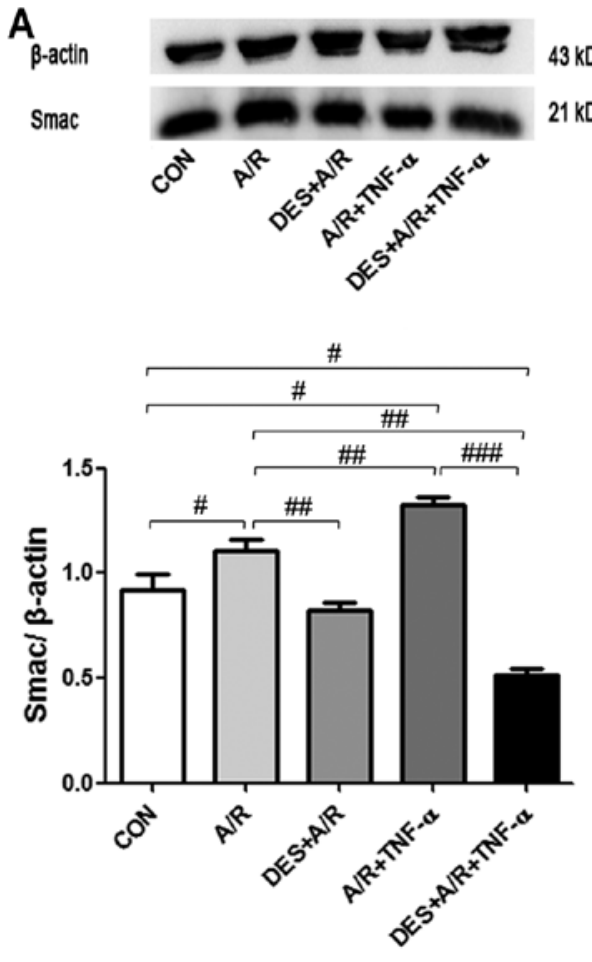

B
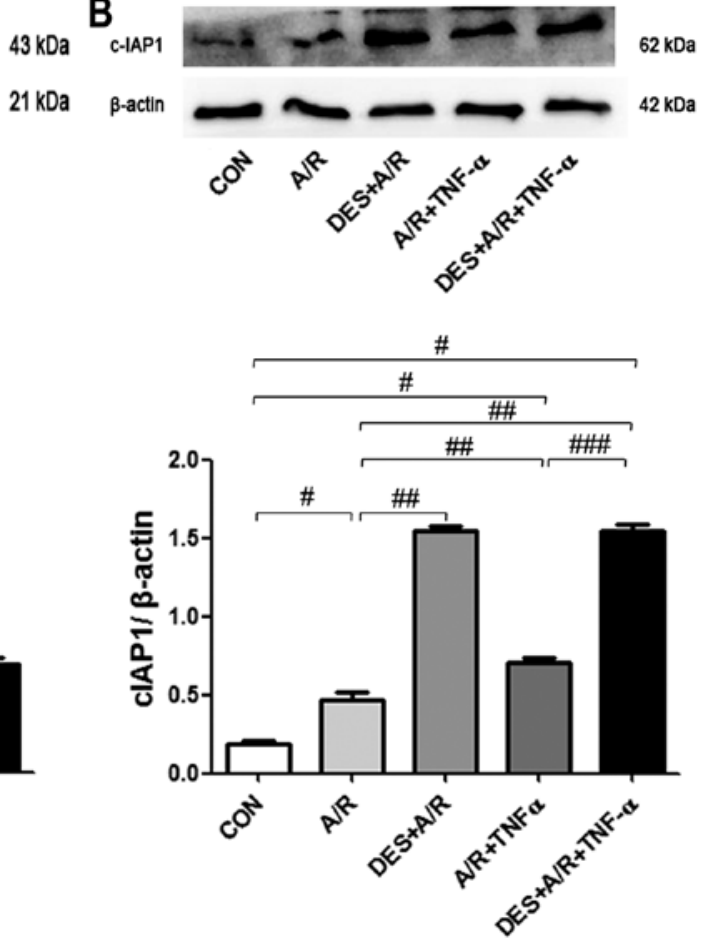

Figure 4. Desflurane preconditioning (DES) attenuates Smac and increases cellular inhibitor of apoptosis 1 (cIAP1) expression in human umbilical vein endothelial cells (HUVECs). Protein levels of (A) Smac and (B) cIAP1 in HUVECS treated as described in Fig. 2, determined by immunoblot analysis. Data are presented as the means $\pm \mathrm{SD}$ (n=3 per group). ${ }^{\#} \mathrm{P}<0.05$ vs. control $(\mathrm{CON}),{ }^{\# \#} \mathrm{P}<0.05$ vs. anoxia/reoxygenation $(\mathrm{A} / \mathrm{R}),{ }^{\# \# \#} \mathrm{P}<0.05$ vs. A/R + tumor necrosis factor $(\mathrm{TNF})-\alpha$.

inflammation), were detected by immunoblot analysis (Fig. 5). In addition, in the HUVECs exposed to $\mathrm{A} / \mathrm{R}$ or $\mathrm{A} / \mathrm{R}$ plus TNF- $\alpha$ elevated mRNA levels of interleukin (IL)-10 and NLRP12 were detected by PCR array. Preconditioning with desflurane increased the mRNA level of IL-10 and NLRP12 in the cells exposed to A/R by 2.40- and 2.16-fold, respectively (Table I), and enhanced the protein level of NLRP12 $(\mathrm{P}=0.0013)$. In the cells exposed to $A / R$ or $A / R$ plus TNF- $\alpha$ higher levels of NLRP12 were noted, and desflurane preconditioning further increased the NLRP12 protein levels ( $\mathrm{P}=0.0118$; Fig. 5). These results suggest that the NLRP12 and IL-10 genes associated with inflammation are invovled in the effects of desflurane preconditioning.
Desflurane preconditioning inhibits the non-canonical $N F-\kappa B$ signaling pathway. To determine whether desflurane preconditioning has an effect on the non-canonical NF- $\kappa \mathrm{B}$ signaling pathway, we measured the levels of NIK, IKK $\alpha$, p52 and RelB in HUVECs exposed to A/R by immunoblot analysis, as illustrated in Fig. 6. The HUVECs exposed to A/R had greater levels of NIK and p100, and and reduced levels of p52 and IKK $\alpha$. Desflurance preconditioning reduced the level of NIK below baseline levels, further increased p100 levels, and further reduced p52 and IKK $\alpha$ levels. A/R in combination with TNF- $\alpha$ increased the levels of NIK, IKK $\alpha$, p100 and RelB. These changes were significantly attenuated by desflurance preconditioning (all $\mathrm{P}<0.05$; Fig. 6). 

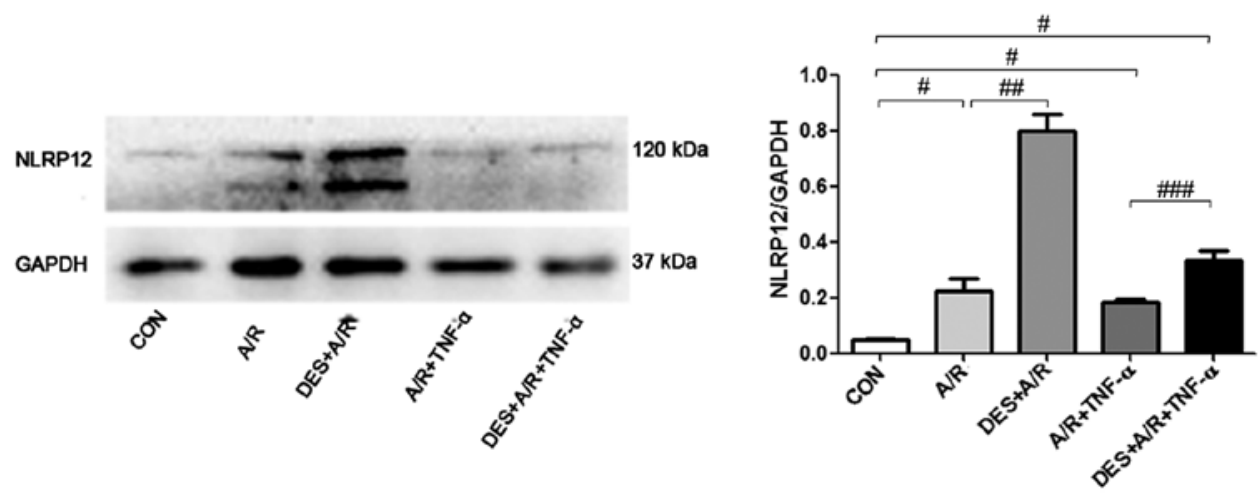

Figure 5. Desflurane preconditioning (DES) increases NLR family, pyrin domain containing 12 (NLRP12) expression in human umbilical vein endothelial cells (HUVECs). Protein levels of NLRP12 in HUVECS were treated as described in Fig. 2, and determined by immunoblot analysis. Data are presented as the means $\pm \mathrm{SD}$ ( $\mathrm{n}=3$ per group). ${ }^{\#} \mathrm{P}<0.05$ vs. control $(\mathrm{CON}),{ }^{\# \#} \mathrm{P}<0.05$ vs. anoxia/reoxygenation $(\mathrm{A} / \mathrm{R}),{ }^{\# \# \#} \mathrm{P}<0.05$ vs. $\mathrm{A} / \mathrm{R}+$ tumor necrosis factor $(\mathrm{TNF})-\alpha$.
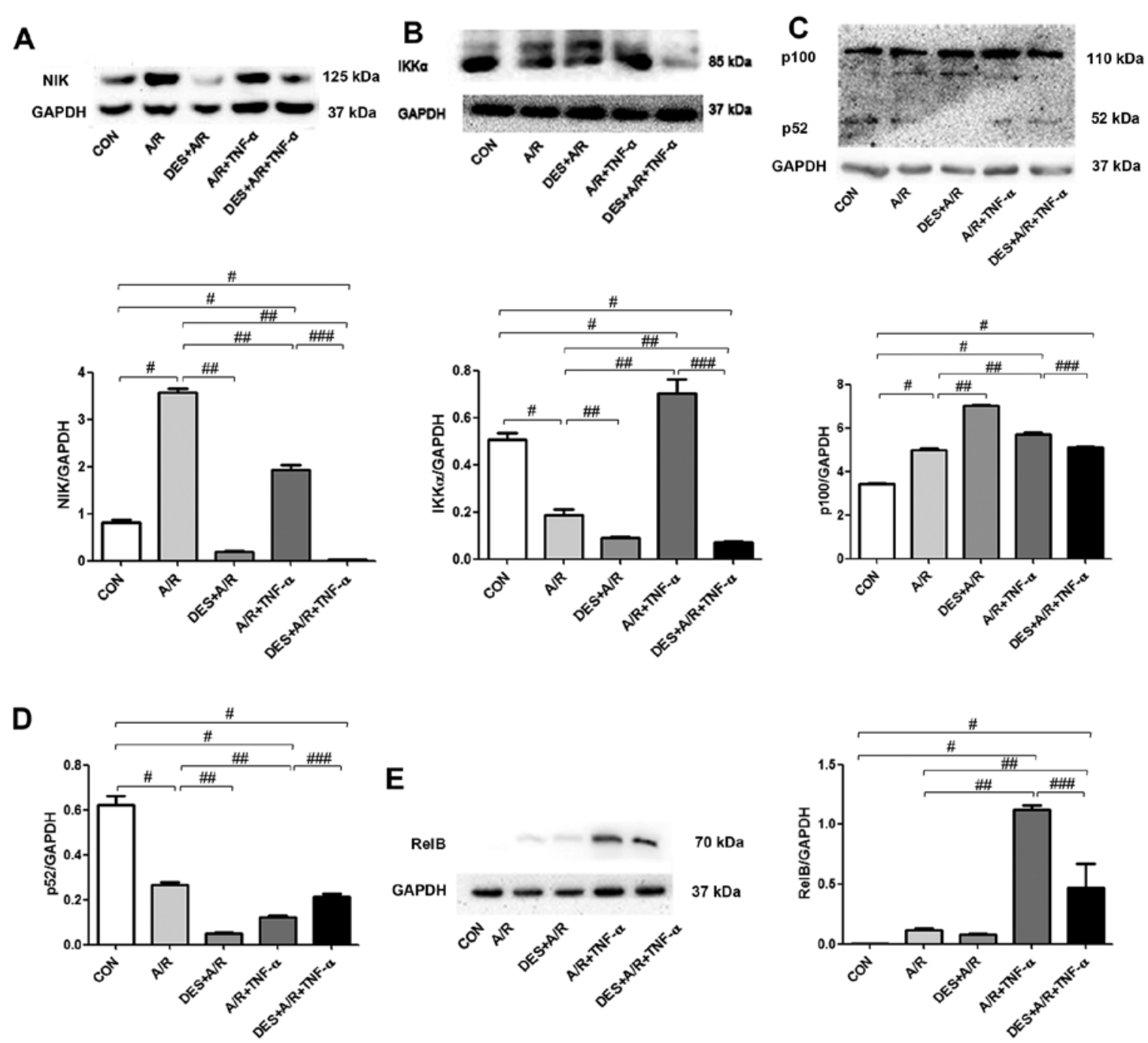

Figure 6. Desflurane preconditioning (DES) influences NF-кB inducing kinase (NIK), IкB kinase (IKK) $\alpha$, p100, p52 and RelB expression in human umbilical vein endothelial cells (HUVECs). Protein levels of (A) NIK, (B) IKK $\alpha$, (C and D) p100 and p52 and (E) RelB-B in HUVECs treated as described in Fig. 2, and determined by immunoblot analysis. Data are presented as the means $\pm \mathrm{SD}\left(\mathrm{n}=3\right.$ per group). ${ }^{\#} \mathrm{P}<0.05$ vs. control $(\mathrm{CON}),{ }^{\# \#} \mathrm{P}<0.05$ vs. anoxia/reoxygenation $(\mathrm{A} / \mathrm{R})$,

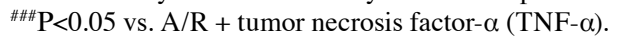

\section{Discussion}

$\mathrm{A} / \mathrm{R}$ has previously been reported to activate NF- $\mathrm{KB}$ in HUVECs, with parallel increases in oxidase stress, inflamma- tory responses and apoptosis $(23,51-53)$. Apoptosis is mediated by an increase in the permeability of the outer mitochondrial membrane (54), leading to the release of apoptogenic factors from the mitochondrial inter-membrane space into the cytosol. 
Apoptogenic factors include Smac, which in turn binds to and neutralizes caspase inhibitors of apoptosis proteins, such as IAPs (57), thereby activating caspases. A previous study indicated that desflurane induced $A \beta$ production and caspase activation under hypoxic conditions (58). Our results, however, suggest that desflurane preconditioning protects endothelial cells by activating anti-apoptotic cIAP1 and decreasing the expression of Smac, thus resulting in decreased levels of apoptosis.

cIAP1 is an NF- $\kappa \mathrm{B}$ responsive gene $(59,60)$. Desflurane preconditioning has previously been reported to activate the canonical NF- $\kappa \mathrm{B}$ pathway $(17,18)$. However, whether volatile anesthetics protect HUVECs against A/R injury through the non-canonical NF- $\mathrm{B}$ signaling pathway or crosstalk with other pathways remains to be established. In the present study, with the use of a human $\mathrm{NF}-\kappa \mathrm{B}$ signaling pathway array, we revealed that NLRP12 expression was upregulated by desflurane preconditioning.

It has previously been reported that NLRP12 suppresses the production of pro-inflammatory cytokines and chemokines (55). Lich and Ting (54) reported that NLRP12 suppressed 'non-canonical' NF- $\kappa \mathrm{B}$ activation. Furthermore, this alternative pathway is activated downstream of TLRs in addition to the TNF family receptors $(61,62)$. Unlike the canonical NF- $\kappa B$ signaling pathway, which can be activated by multiple upstream kinases, the non-canonical pathway is strictly dependent upon the kinase NIK (63). Upon activation, NIK recruits IKK $\alpha$ and $\mathrm{NF}-\kappa \mathrm{B} 2 / \mathrm{p} 100$, which in turn leads to the processing of p100 into its active form, $\mathrm{p} 52$. In the present study, we found that desflurane preconditioning downregulated the expression of NIK, IKK $\alpha$, p52 and upregulated the expression of p100 during A/R-induced injury. These results validated those of previous studies indicating that desflurane preconditioning inhibits the non-canonical NF- $\kappa \mathrm{B}$ signaling pathway and thus protects cells against $\mathrm{A} / \mathrm{R}$ induced cell injury $(1,18)$.

In conclusion, in this study, we demonstrated that desflurane preconditioning attenuated HUVEC inflammatory responses to A/R. Desflurane preconditioning upregulated cIAP1 and NLRP12 expression, and downregulated Smac, NIK, IKK $\alpha$ and p52 expression, ameliorating cellular stress processes and apoptosis during $\mathrm{A} / \mathrm{R}$. As desflurane is increasingly applied in clinical settings, the role of desflurane in $A / R$ injury needs to be further characterized, in an aim to obtain a deeper understanding of the cellular responses to desflurane, which may support the extension of this therapeutic strategy in the treatment of A/R-induced inflammatory responses.

\section{Acknowledgements}

The present study was supported, in part, by a grant from the National Natural Science Foundation of China (no. 30972838).

\section{References}

1. Yi J, Zheng Y, Miao C, Tang J and Zhu B: Desflurane preconditioning induces oscillation of $N F-\kappa B$ in human umbilical vein endothelial cells. PLoS One 8: e66576, 2013.

2. Ding WG, Zhou HC, Cui XG, Li WZ, Guo YP, Zhang B and Liu W: Anti-apoptotic effect of morphine-induced delayed preconditioning on pulmonary artery endothelial cells with anoxia/reoxygenation injury. Chin Med J (Engl) 121: 1313-1318, 2008.
3. Yu EZ,Li YY,Liu XH,Kagan Eand McCarron RM: Antiapoptotic action of hypoxia-inducible factor-1 alpha in human endothelial cells. Lab Invest 84: 553-561, 2004.

4. Hu Y, Li L, Yin W, Shen L, You B and Gao H: Protective effect of proanthocyanidins on anoxia-reoxygenation injury of myocardial cells mediated by the PI3K/Akt/GSK-3 $\beta$ pathway and mitochondrial ATP-sensitive potassium channel. Mol Med Rep 10: 2051-2058, 2014.

5. Rui $\mathrm{T}$ and Tang Q: IL-33 attenuates anoxia/reoxygenationinduced cardiomyocyte apoptosis by inhibition of $\mathrm{PKC} \beta / \mathrm{JNK}$ pathway. PLoS One 8: e56089, 2013

6. Zhang C, Lin G, Wan W, Li X, Zeng B, Yang B and Huang C: Resveratrol, a polyphenol phytoalexin, protects cardiomyocytes against anoxia/reoxygenation injury via the TLR4/NF- $\kappa \mathrm{B}$ signaling pathway. Int J Mol Med 29: 557-563, 2012.

7. Li WJ, Nie SP, Chen Y, Xie MY, He M, Yu Q and Yan Y: Ganoderma atrum polysaccharide protects cardiomyocytes against anoxia/reoxygenation-induced oxidative stress by mitochondrial pathway. J Cell Biochem 110: 191-200, 2010.

8. Zaugg M, Lucchinetti E, Garcia C, Pasch T, Spahn DR and Schaub MC: Anaesthetics and cardiac preconditioning. Part II. Clinical implications. Br J Anaesth 91: 566-576, 2003.

9. Zaugg M, Lucchinetti E, Uecker M, Pasch T and Schaub MC: Anaesthetics and cardiac preconditioning. Part I. Signalling and cytoprotective mechanisms. Br J Anaesth 91: 551-565, 2003.

10. Piriou V, Chiari P, Lhuillier F, Bastien O, Loufoua J, Raisky O, David JS, Ovize M and Lehot JJ: Pharmacological preconditioning: comparison of desflurane, sevoflurane, isoflurane and halothane in rabbit myocardium. Br J Anaesth 89: 486-491, 2002.

11. Haelewyn B, Zhu L, Hanouz JL, Persehaye E, Roussel S, Ducouret P and Gérard JL: Cardioprotective effects of desflurane: effect of timing and duration of administration in rat myocardium. Br J Anaesth 92: 552-557, 2004.

12. Suleiman MS, Zacharowski K and Angelini GD: Inflammatory response and cardioprotection during open-heart surgery: the importance of anaesthetics. Br J Pharmacol 153: 21-33, 2008.

13. Wang H, Lu S, Yu Q, Liang W, Gao H, Li P, Gan Y, Chen J and Gao Y: Sevoflurane preconditioning confers neuroprotection via anti-inflammatory effects. Front Biosci (Elite Ed) 3: 604-615, 2011.

14. Boost KA, Flondor M, Hofstetter C, Platacis I, Stegewerth K, Hoegl S, Nguyen T, Muhl H and Zwissler B: The beta-adrenoceptor antagonist propranolol counteracts anti-inflammatory effects of isoflurane in rat endotoxemia. Acta Anaesthesiol Scand 51: 900-908, 2007.

15. Liang Y, Li Z, Mo N, Li M, Zhuang Z, Wang J, Wang Y and Guo X: Isoflurane preconditioning ameliorates renal ischemiareperfusion injury through antiinflammatory and antiapoptotic actions in rats. Biol Pharm Bull 37: 1599-1605, 2014.

16. Bedirli N, Demirtas CY, Akkaya T, Salman B, Alper M, Bedirli A and Pasaoglu H: Volatile anesthetic preconditioning attenuated sepsis induced lung inflammation. J Surg Res 178: e17-e23, 2012.

17. Biao Z, Zhanggang $X$, Hao J, Changhong $M$ and Jing C: The in vitro effect of desflurane preconditioning on endothelial adhesion molecules and mRNA expression. Anesth Analg 100: 1007-1013, 2005.

18. Li Y, Zhang X, Zhu B and Xue Z: Desflurane preconditioning inhibits endothelial nuclear factor-kappa-B activation by targeting the proximal end of tumor necrosis factor-alpha signaling. Anesth Analg 106: 1473-1479, 2008.

19. Kopp EB and Ghosh S: NF-kappaB and rel proteins in innate immunity. Adv Immunol 58: 1-27, 1995.

20. Tsung A, Hoffman RA, Izuishi K, Critchlow ND, Nakao A, Chan MH, Lotze MT, Geller DA and Billiar TR: Hepatic ischemia/reperfusion injury involves functional TLR4 signaling in nonparenchymal cells. J Immunol 175: 7661-7668, 2005.

21. Donnahoo KK, Meldrum DR, Shenkar R, Chung CS, Abraham E and Harken AH: Early renal ischemia, with or without reperfusion, activates NFkappaB and increases TNF-alpha bioactivity in the kidney. J Urol 163: 1328-1332, 2000.

22. Baeuerle PA, Baltimore D: NF-kappaB: ten years after. Cell 87: 13-20, 1996.

23. Kokura S, Wolf RE, Yoshikawa T, Granger DN and Aw TY: T-lymphocyte-derived tumor necrosis factor exacerbates anoxiareoxygenation-induced neutrophil-endothelial cell adhesion. Circ Res 86: 205-213, 2000.

24. Karakurum M, Shreeniwas R, Chen J, Pinsky D, Yan SD, Anderson M, Sunouchi K, Major J, Hamilton T and Kuwabara K: Hypoxic induction of interleukin-8 gene expression in human endothelial cells. J Clin Invest 93: 1564-1570, 1994. 
25. Loop T, Dovi-Akue D, Frick M, Roesslein M, Egger L, Humar M, Hoetzel A, Schmidt R, Borner C, Pahl HL, et al: Volatile anesthetics induce caspase-dependent, mitochondria-mediated apoptosis in human T lymphocytes in vitro. Anesthesiology 102: $1147-1157,2005$.

26. Coope HJ, Atkinson PG, Huhse B, Belich M, Janzen J,Holman MJ, Klaus GG, Johnston LH and Ley SC: CD40 regulates the processing of NF-kappaB2 p100 to p52. EMBO J 21: 5375-5385, 2002.

27. Ganeff C, Remouchamps C, Boutaffala L, Benezech C, Galopin G, Vandepaer S, Bouillenne F, Ormenese S, Chariot A, Schneider $\mathrm{P}$, et al: Induction of the alternative NF- $\kappa$ B pathway by lymphotoxin $\alpha \beta$ (LT $\alpha \beta)$ relies on internalization of LT $\beta$ receptor Mol Cell Biol 31: 4319-4334, 2011.

28. Claudio E, Brown K, Park S, Wang H and Siebenlist U: BAFFinduced NEMO-independent processing of NF-kappa B2 in maturing B cells. Nat Immunol 3: 958-965, 2002.

29. Dejardin E: The alternative NF-kappaB pathway from biochemistry to biology: pitfalls and promises forfuture drug development Biochem Pharmacol 72: 1161-1179, 2006.

30. Zaki MH, Boyd KL, Vogel P, Kastan MB, Lamkanfi M and Kanneganti TD: The NLRP3 inflammasome protects against loss of epithelial integrity and mortality during experimental colitis. Immunity 32: 379-391, 2010.

31. Allen IC, TeKippe EM, Woodford RM, Uronis JM, Holl EK, Rogers AB, Herfarth HH, Jobin C and Ting JP: The NLRP3 inflammasome functions as a negative regulator of tumorigenesis during colitis-associated cancer. J Exp Med 207: 1045-1056, 2010.

32. Hu B, Elinav E, Huber S, Strowig T, Hao L, Hafemann A, Jin C, Wunderlich C, Wunderlich T, Eisenbarth SC and Flavell RA: Microbiota-induced activation of epithelial IL-6 signaling links inflammasome-driven inflammation with transmissible cancer. Proc Natl Acad Sci USA 110: 9862-9867, 2013

33. Hu B, Elinav E, Huber S, Booth CJ, Strowig T, Jin C Eisenbarth SC and Flavell RA: Inflammation-induced tumorigenesis in the colon is regulated by caspase-1 and NLRC4. Proc Natl Acad Sci USA 107: 21635-21640, 2010.

34. Chen GY: Role of Nlrp6 and Nlrp12 in the maintenance of intestinal homeostasis. Eur J Immunol 44: 321-327, 2014.

35. Zhang L, Mo J, Swanson KV, Wen H, Petrucelli A, Gregory SM, Zhang Z, Schneider M, Jiang Y, Fitzgerald KA, et al: NLRC3, a member of the NLR family of proteins, is a negative regulator of innate immune signaling induced by the DNA sensor STING. Immunity 40: 329-341, 2014.

36. Xia X, Cui J, Wang HY, Zhu L, Matsueda S, Wang Q, Yang X, Hong J, Songyang Z, Chen ZJ and Wang RF: NLRX1 negatively regulates TLR-induced NF-kappaB signaling by targeting TRAF6 and IKK. Immunity 34: 843-853, 2011.

37. Lich JD, Williams KL, Moore CB, Arthur JC, Davis BK, Taxman DJ and Ting JP: Monarch-1 suppresses non-canonical NF-kappaB activation and p52-dependent chemokine expression in monocytes. Journal of immunology 178: 1256-1260, 2007.

38. Wang L, Manji GA, Grenier JM, Al-Garawi A, Merriam S, Lora JM, Geddes BJ, Briskin M, DiStefano PS and Bertin J: PYPAF7, a novel PYRIN-containing Apaf1-like protein that regulates activation of NF-kappa $B$ and caspase-1-dependent cytokine processing. J Biol Chem 277: 29874-29880, 2002.

39. Vladimer GI, Weng D, Paquette SW, Vanaja SK, Rathinam VA, Aune MH, Conlon JE, Burbage JJ, Proulx MK, Liu Q, et al: The NLRP12 inflammasome recognizes Yersinia pestis. Immunity 37: 96-107, 2012.

40. Ataide MA, Andrade WA, Zamboni DS, Wang D, Souza Mdo C, Franklin BS, Elian S, Martins FS, Pereira D, Reed G, et al: Malaria-induced NLRP12/NLRP3-dependent caspase-1 activation mediates inflammation and hypersensitivity to bacterial superinfection. PLoS Pathog 10: e1003885, 2014.

41. Allen IC, McElvania-TeKippe E, Wilson JE, Lich JD, Arthur JC, Sullivan JT, Braunstein M and Ting JP: Characterization of NLRP12 during the in vivo host immune response to Klebsiella pneumoniae and Mycobacterium tuberculosis. PloS One 8: e60842, 2013.

42. Allen IC, Wilson JE, Schneider M, Lich JD, Roberts RA, Arthur JC, Woodford RM, Davis BK, Uronis JM, Herfarth HH, et al: NLRP12 suppresses colon inflammation and tumorigenesis through the negative regulation of noncanonical NF-kappaB signaling. Immunity 36: 742-754, 2012.

43. Allen IC, Lich JD, Arthur JC, et al.: Characterization of NLRP12 during the development of allergic airway disease in mice. PloS one 7: e30612, 2012
44. Zaki MH, Vogel P, Malireddi RK, Body-Malapel M, Anand PK, Bertin J, Green DR, Lamkanfi M and Kanneganti TD: The NOD-like receptor NLRP12 attenuates colon inflammation and tumorigenesis. Cancer Cell 20: 649-660, 2011.

45. Pinheiro AS, Eibl C, Ekman-Vural Z, Schwarzenbacher R and Peti W: The NLRP12 pyrin domain: structure, dynamics, and functional insights. J Mol Biol 413: 790-803, 2011.

46. Arthur JC, Lich JD, Ye Z, Allen IC, Gris D, Wilson JE, Schneider M, Roney KE, O'Connor BP, Moore CB, et al: Cutting edge: NLRP12 controls dendritic and myeloid cell migration to affect contact hypersensitivity. J Immunol 185: 4515-4519, 2010.

47. Baudin B, Bruneel A, Bosselut N and Vaubourdolle M: A protocol for isolation and culture of human umbilical vein endothelial cells. Nat Protoc 2: 481-485, 2007.

48. Takahashi K, Sawasaki Y, Hata J, Mukai K and Goto T: Spontaneous transformation and immortalization of human endothelial cells. In Vitro Cell Dev Biol 26: 265-274, 1990.

49. Koyama T, Temma K and Akera T: Reperfusion-induced contracture develops with a decreasing [Ca2+]i in single heart cells. Am J Physiol 261: H1115-H1122, 1991.

50. Mouithys-Mickalad A, Mathy-Hartert M, Du G, Sluse F, Deby C, Lamy M and Deby-Dupont G: Oxygen consumption and electron spin resonance studies of free radical production by alveolar cells exposed to anoxia: inhibiting effects of the antibiotic ceftazidime. Redox Rep 7: 85-94, 2002.

51. Ichikawa H, Flores S, Kvietys PR, Wolf RE, Yoshikawa T, Granger DN and Aw TY: Molecular mechanisms of anoxia/ reoxygenation-induced neutrophil adherence to cultured endothelial cells. Circ Res 81: 922-931, 1997.

52. Cepinskas G1, Lush CW and Kvietys PR: Anoxia/reoxygenationinduced tolerance with respect to polymorphonuclear leukocyte adhesion to cultured endothelial cells. A nuclear factor-kappaBmediated phenomenon. Circ Res 84: 103-12, 1999.

53. Rupin A, Paysant J, Sansilvestri-Morel P, Lembrez N, Lacoste JM, Cordi A and Verbeuren TJ: Role of NADPH oxidase-mediated superoxide production in the regulation of E-selectin expression by endothelial cells subjected to anoxia/reoxygenation. Cardiovasc Res 63: 323-30, 2004.

54. Lich JD and Ting JP: Monarch-1/PYPAF7 and other CATERPILLER (CLR, NOD, NLR) proteins with negative regulatory functions. Microbes Infect 9: 672-676, 2007.

55. Williams KL, Lich JD, Duncan JA, Reed W, Rallabhandi P, Moore C, Kurtz S, Coffield VM, Accavitti-Loper MA, Su L, et al: The CATERPILLER protein monarch-1 is an antagonist of toll-like receptor-, tumor necrosis factor alpha-, and Mycobacterium tuberculosis-induced pro-inflammatory signals. J Biol Chem 280: 39914-39924, 2005.

56. Green DR and Kroemer G: The pathophysiology of mitochondrial cell death. Science 305: 626-629, 2004.

57. Hennessy EJ, Saeh JC, Sha L, MacIntyre T, Wang H, Larsen NA, Aquila BM, Ferguson AD, Laing NM and Omer CA: Discovery of aminopiperidine-based Smac mimetics as IAP antagonists. Bioorg Med Chem Lett 22: 1690-1694, 2012.

58. Zhang B, Dong Y, Zhang G, Moir RD, Xia W, Yue Y, Tian M, Culley DJ, Crosby G, Tanzi RE and Xie Z: The inhalation anesthetic desflurane induces caspase activation and increases amyloid beta-protein levels under hypoxic conditions. J Biol Chem 283: 11866-11875, 2008

59. Mahoney DJ, Cheung HH, Mrad RL, Plenchette S, Simard C, Enwere E, Arora V, Mak TW, Lacasse EC, Waring J and Korneluk RG: Both cIAP1 and cIAP2 regulate TNFalphamediated NF-kappaB activation. Proc Natl Acad Sci USA 105: 11778-11783, 2008

60. Varfolomeev E and Vucic D: (Un)expected roles of c-IAPs in apoptotic and NF-kappaB signaling pathways. Cell Cycle 7: 1511-1521, 2008.

61. Vatsyayan J, Qing G, Xiao G and Hu J: SUMO1 modification of NF-kappaB2/p100 is essential for stimuli-induced p100 phosphorylation and processing. EMBO Rep 9: 885-890, 2008.

62. Heusch M, Lin L, Geleziunas R and Greene WC: The generation of nfkb2 p52: mechanism and efficiency. Oncogene 18: 64-6208, 1999.

63. Xiao G, Fong A and Sun SC: Induction of p100 processing by NF-kappaB-inducing kinase involves docking IkappaB kinase alpha (IKKalpha) to p100 and IKKalpha-mediated phosphorylation. J Biol Chem 279: 30099-30105, 2004. 